\title{
How Earmarking Government Revenue Affects Efficiency of Road Construction and Maintenance
}

\author{
Ramon Christen ${ }^{*}$, Nils C. Soguel ${ }^{\dagger}$ \\ * Corresponding author; PricewaterhouseCoopers AG Switzerland; Bahnhofplatz 10; 3001 Bern; Switzerland; Email: \\ ramon.christen@pwc.ch, Phone Number: +41 587927580 \\ + The Swiss Graduate School of Public Administration-IDHEAP, University of Lausanne; Rue de la Mouline 28; 1015 Lausanne; Switzerland; \\ Email: nils.soguel@unil.ch; Phone Number: +41 216926850
}

This is the accepted version of the paper published as: Christen, R., \& Soguel, N. C. (2021). How Earmarking Government Revenue Affects Efficiency of Road Construction and Maintenance. Public Finance Review, 49(1), 136-163. https://doi.org/10.1177/1091142120980348. The pagination corresponds to that of the version published in the journal.

\begin{abstract}
It is common practice to assign revenue to accomplish specific governmental tasks in general, and to provide transport infrastructure in particular. However, neither the literature in public administration nor in public choice has reached a consensus about the effects that earmarking has on efficiency. Building on earlier public choice models, we argue that this mechanism prevents budget debates from occurring and reduces the incentives for ministers to monitor the colleagues whose budgets are financed by earmarked revenues. These latter tend to overuse public resources, thus increasing inefficiency. A stochastic frontier model fed with data from Swiss cantonal ministries of transport from 2000 to 2016 tests this hypothesis. The results reveal a negative effect of earmarking on efficiency. For every 1,000 additional
\end{abstract}


Swiss francs per capita financed out of an earmarked fund, the input requirement increases by 5.4 percent on average.

Keywords: Roads, Earmarked revenue, Efficiency, Public Choice, Stochastic Frontier Analysis

\section{Background}

This paper argues that dedicating specific public revenues for particular expenditure purposes has a negative effect on the efficiency of public service provision. This earmarking mechanism is sometimes called ring-fenced funds, recycled revenues, segregated funding, autonomous revenue streams, pork-barrel spending, tax hypothecation, or lockboxing (Jackson, 2013). It is used in various policy areas, including transport infrastructure, telecommunication, security, health, education, environment, and social security, as reported by Roberts (2002) for the US or McCleary (1991) for other countries.

A government is efficient compared to its peers if it provides the maximum quantity or quality of public services (i.e. outputs) given its bundle of expenditures (i.e. inputs). In contrast, a government provides its services inefficiently if, for instance, it overspends for excessively large offices or unproductive programs, et cetera. In technical terms, the state entity's efficiency results from the distance to the benchmark, which is the production frontier consisting of the optimal combinations of inputs and outputs.

We purport that earmarking interferes in budget negotiations between ministers sitting in the executive branch of the government and later in parliament. The earmarked revenue is not only excluded from any bargaining, but tasks funded in such a way and their supervisory ministers are also less likely to be overseen by other ministers. Therefore, earmarking prevents reciprocal checks across and between ministers and ministries. This premise motivates our main research question: Does earmarking, together with other revenue characteristics, negatively influence the efficiency of road infrastructure provision, and to what extent? Answering this means first measuring the quantitative importance of earmarked funds. Afterwhich, the effect on efficiency can be econometrically estimated by combining several output and input variables to approach the efficiency and by including revenue characteristics as environmental factors. In our model calibrated for the Swiss cantons, earmarking has 
a negative influence on efficiency. For every 1,000 additional Swiss francs per capita financed out of an earmarked fund, the input requirement increases by 5.4 percent on average.

This finding sheds light on the existing literature which so far has remained divided and inconclusive in trying to connect earmarking and efficiency. Among the various kinds of government revenues, earmarked ones were early recognised as bearing similarities to transfers or debt financing. Oates (1985) subsumed them under the wider term of fiscal illusion and argues that revenue characteristics might influence the creation of a government budget.

For its part, classic public administration literature claims that earmarking harmfully affects efficiency because a predefined budget allocation limits the government's flexibility to maximize the social welfare (Deran, 1965; Lee and Wagner, 1991). Non-earmarked revenues give the benevolent bureaucrat the possibility to optimally allocate ressouces (Schönenberger, 2013). By contrast, the public choice theory considers earmarking a disciplinary tool which hinders politicians from abusing their influence over the budgetary process and fosters a more efficient provision of public services. According to Buchanan (1963), earmarking makes it possible to redress tie-in sales offered by the government under general fund financing, as the voter has a direct influence on budget allocation. In this sense, it can even help fight rigid budgeting procedures (Bird, 1982). Linking a levy to a specified public service provides the administration with more accurate information about the actual demand for a public good since the beneficiary pays for his own utility (Bird and Jun, 2005). Enforcing earmarking can be seen as a substitute for a direct user charge if this latter is not feasible (Lee and Wagner, 1991).

The empirical evidence is very scarce and patchy. To the best of our knowledge, indeed only Martínez (2014) sets the efficiency of public service provision as the dependent variable and examined the influence of earmarked revenue stemming from oil royalties on the provision of local public goods in Colombian municipalities. The results show that increases in the general budget boost public goods indicators at least ten times more than an equivalent increase in earmarked revenues. Other empirical contributions in this field examined the effect of earmarked revenues on public expenditure. They mostly focus on U.S. states and on a limited number of government functions. In sum, these studies argue that earmarking indeed increases expenditure for the concerned function of government, but it partly crowds out the existing general fund financing and in so doing also leads to higher spending for other functions (Nesbit and Kreft 2009, Afonso 2015). Yet, since higher expenditures by no means 
automatically lead to inefficiency, the results of these studies do not substantially contribute to the question approached here. Nevertheless, being aware of a possible crowding-out effect is important in order to understand why the Swiss case is a particularly interesting one for analysing earmarks - as outlined in Section four.

Our study applies stochastic frontier analysis for the first time as a way to measure the effect earmarking has on efficiency in road infrastructure provision; the technique has been used before in connection with efficiency concerns other than earmarking (see Kalb 2009; Seifert and Nieswand 2014; Widmer and Zweifel 2012). The twenty-six Swiss cantons (the institutional equivalent of provinces or states in other countries) provide a fertile empirical ground for two reasons. First, they have relatively detailed and accurate data for the sample period of 2000 to 2016 . Second, they enjoy considerable fiscal autonomy, which means a large degree of variation in many areas. The cantons face minimal federal restrictions in terms of their tax systems, indebtedness, or how they allocate their budgets. Consequently, cantons have considerable latitude in deciding which services they want to provide to their citizens and to what extent. This pronounced autonomy also manifests in a high degree of self-financing of public services, including road construction and maintenance.

The paper is organised as follows. The next section describes in detail a model in which the efficiency of the public service provision is hindered by what we call the "debate prevention" induced by earmarked revenues. The third section introduces stochastic frontier analysis and explains how the method estimates the distance to the production frontier by combining inputs and outputs in a context of environmental factors. Following that, the fourth section presents how we measure earmarking for financing the road infrastructure provision in the Swiss cantons and the quantitative importance of the phenomenon over seventeen years for twenty-one out of twenty-six cantons. The other data used to compute the stochastist frontier are also specified in this section. Section 5 presents the estimation results and provides the answers to our research question. The final section is devoted to the conclusions drawn from the study and to the relevance of these results for policymakers.

\section{A Theoretical Model of Debate Prevention}

The debate prevention model follows along from the idea of electoral competition where candidates and incumbents can obtain positive rents if the two politicians are no perfect substitute for each other because of an ideological bias. Without specifying what they mean exactly by it, Persson 
and Tabellini (2002) argue that transaction costs determine the amount of rent politicians can divert from the total budget. We extend this model in two ways. First, we specify transaction costs as being the effort politicians make to hide rent appropriation, which in turn depends on the monitoring effort of other ministers. Since rents generate no public service, they lead to overspending and thus to inefficiency. Second, the debate prevention model is oriented to a political system in which the political executive is organized as a governing council with elected ministers sharing equal power, each of whom manages a ministry. This is the case in the Swiss system on all three state layers. However, the model is easily transferable to a mayoral government or to a president who presides over a cabinet of ministers. Furthermore, we assume that the earmarked funds are exogenous, which comes close to the Swiss reality in the short run.

The governing council plays an important role in allocating resources because its members engage in various rounds of debate with respect to the share each ministry receives of the total government budget. In order to maximize his or her share of the total budget (Niskanen 1975), ministers mount monitoring efforts to question the proposed programs and budget claims of colleagues. This intense screening increases the probability of revealing weaknesses and finding potential savings in the proposed policy programs, outcomes which free up the claimed funds and bring them back to the negotiation table. Thus, more monitoring means higher transaction costs for siphoning off monetary rents.

Now, imagine that minister A manages an earmarked fund specifically designed to finance one particular task, for which the minister is solely responsible. During all the budget debates, the budgetary fraction behind minister $A^{\prime} \quad s$ earmarking wall remains undisputable. Out of $A$ ' $s$ requested budget, there is only a small part up for discussion and this alleviates any incentive to monitor A's policy programs in the first place. Being less monitored (i.e. facing lower transaction costs to achieve rents), minister A enjoys a larger leeway to generate budgetary slack and consequently she offers the services within her domain less efficiently (she uses more inputs to generate the same amount of outputs). ${ }^{1}$ In general, the hypothesis is that the larger the share behind earmark-walls, the less incentive the ministers have to monitor each other and the less efficient the public service provision. Put differently, a high level of earmarked revenue share partly releases ministers from debating during the budgetary process. 


\section{Methodology}

There are several possibilities to econometrically combine inputs, outputs, and environmental variables with the intention to explain efficiency variation. Given the available data, a distance function is the most suitable approach here. Not only does it make it possible to separate random noise from inefficiency, it also introduces various inputs and outputs (Shephard 1953). The input distance function can be derived from the transformation function $A f(x \theta, y)=1$, where $\boldsymbol{y}$ is a vector of $q$ outputs, $\boldsymbol{x}$ a vector of $w$ input costs, and A covers variables or functions that affect the entire production but not the inputs or outputs individually; the efficiency term $\theta$ lies between zero and one (Kumbhakar 2012). The transformation function describes how the inputs, deflated by an efficiency factor, produce a set of outputs. We impose the standard assumption of input homogeneity of degree one, which means that if the inputs are multiplied by some factor, then the output is multiplied by some power of this factor. ${ }^{2}$ Homogeneity of degree one in inputs enables us to rewrite the above transformation function as $\theta x_{1} f(\widetilde{\boldsymbol{x}}, \boldsymbol{y})=A$ where $\widetilde{\boldsymbol{x}}=\frac{\boldsymbol{x}}{x_{1}}$, i.e. all $w$ inputs except the first are divided by the arbitrarily chosen input $x_{1} \cdot{ }^{3}$ Taking logs and rearranging yields $\ln x_{1}=-\ln f(\widetilde{\boldsymbol{x}}, \boldsymbol{y})+\ln A-\ln \theta$. Define $\ln A:=a$ and $\theta:=\exp (-u)$ to get the generalized input distance function of $\ln x_{1}=a-\ln f(\widetilde{\boldsymbol{x}}, \boldsymbol{y})+u{ }^{4}$

In order to be able to estimate the parameters of interest, we first need to specify the functional form of $f(\widetilde{\boldsymbol{x}}, \boldsymbol{y})$. Given the limited number of observations, the Cobb-Douglas specification seems appropriate as it holds the number of parameters to be estimated at a reasonable level. At the same time, it is rather restrictive in terms of the elasticity of substitution and scale properties. Hence, we also apply the translog specification. Second, the econometric estimation involves stochastic noise $v_{i}$ for each individual $i$, which also needs to be added to the estimation equation. Taken together, the stochastic noise and the inefficiency constitute the error term of the estimation equation, i.e. $\varepsilon_{i}=$ $u_{i}+v_{i}$. To identify both the noise term $v_{i}$ and the inefficiency term $u_{i}$ properly, they need to be individually specified. While the noise term is usually assumed to follow an independent and identical normal distribution with a zero mean, pondering the distribution of the inefficiency term encouraged researchers to come up with numerous models. For instance, the inefficiency term $u_{i}$ could be halfnormally or truncated-normally distributed. The different approaches vary particularly in the number of parameters to be estimated. More parameters mean more flexibility but also add complexity to the estimation. To incorporate environmental variables into the model, we parametrize the mean of the 
inefficiency term $u_{i}$. Thereby, efficiency is conditioned on contextual factors (Kumbhakar, Wang, and Horncastle 2015).

Third, as in other econometric issues, the exploitation of panel data opens up new possibilities for isolating further parameters or identifying the parameters of interest more appropriately. Having several observations of the same individual also makes it possible to exclude fixed effects. Both, the true random- and the true fixed-effect model splits the error term into three parts, i.e. $\varepsilon_{i}=u_{i t}+\alpha_{i}+$ $v_{i t}$ (Greene 2005). The term $u_{i t}$ thereby entails only time-variant inefficiency. On one hand, taking all persistency out of $u_{i t}$ eliminates the risk of confounding some unobserved individual fixed effects $\alpha_{i}$ with time-persistent inefficiency. On the other hand, a latent time-persistent inefficiency remains unidentified too. The aim here is to explain efficiency differences based exclusively on time-varying environmental variables, which renders time-persistent efficiency estimates redundant. The input distance functions specified as Cobb-Douglas (CD) and translog (TL) are estimated with the true random- and the true fixed-effect model as follows:

$$
\begin{aligned}
& \mathrm{CD}: \ln \left(x_{1 i t}\right)=\alpha_{0}+\alpha_{i}+\sum_{r}^{q} \beta_{r} \ln \left(y_{r i t}\right)+\sum_{j=2}^{w} \gamma_{j} \ln \left(\frac{x_{j i t}}{x_{1 i t}}\right)+u_{i t}+v_{i t} \\
& \mathrm{TL}: \ln \left(x_{1 i t}\right)=\alpha_{0}+\alpha_{i}+\sum_{r} \alpha_{r} \ln \left(y_{r i t}\right)+\frac{1}{2} \sum_{r} \sum_{k} \alpha_{r} \ln \left(y_{r i t}\right) \ln \left(y_{k i t}\right) \\
& \quad+\sum_{j=2} \beta_{j} \ln \left(\frac{x_{j i t}}{x_{1 i t}}\right)+\frac{1}{2} \sum_{j=2} \sum_{l=2} \beta_{j} \ln \left(\frac{x_{j i t}}{x_{1 i t}}\right) \ln \left(\frac{x_{j i t}}{x_{1 i t}}\right) \\
& \quad+\sum_{j=2} \sum_{k=2} \gamma_{j} \ln \left(\frac{x_{j i t}}{x_{1 i t}}\right) \ln \left(y_{k i t}\right)+u_{i t}+v_{i t}
\end{aligned}
$$

where $\mathbb{E}\left[\alpha_{i} \mid x_{j i t}, y_{\text {rit }}\right]=0 \quad$ [random-effect $]$ or $\mathbb{E}\left[\alpha_{i} \mid x_{j i t}, y_{\text {rit }}\right] \neq 0$ [fixed-

$$
\begin{gathered}
\text { effect }] \\
u_{i t} \sim N^{+}\left(\mu_{i t}, \sigma_{u}^{2}\right) \quad \text { with } \quad \mu_{i t}=\boldsymbol{\delta}^{\prime} \boldsymbol{z}_{i t} \\
v_{i t} \sim N\left(0, \sigma_{v}^{2}\right)
\end{gathered}
$$

Similar to the random- and fixed effects models of linear regression models, the true fixed-effects model is less efficient but still consistent even if the fixed effect is correlated with the dependent variable. Hence, in order to impose fewer restrictions on the model, the true fixed-effects model serves 
here as a standard estimator whereas we apply the true random-effects estimator as a robustness check. In both models, the inefficiency term $u_{i t}$ indicates the percentage overuse of inputs owed to inefficiency. After the estimation of Equation (1) and (2), the technical efficiency can be obtained through $T E_{i t}=\mathbb{E}\left[\exp \left(-u_{i t}\right) \mid \varepsilon_{i t}\right]$ (Battese and Coelli 1988).

Interpreting the coefficients of the environmental variables $(\boldsymbol{\delta})$ is not straightforward. As they appear in a non-linear fashion in the estimation equation, a direct interpretation would be misleading. Wang (2002) and Kumbhakar and Sun (2013) provide the necessary modifications to obtain the marginal effects on inefficiency. ${ }^{5}$ They also show that the effects are monotonic, using the specification we apply here. In other words, even if the coefficient per se might not be informative without modifications, its sign is. Finally, it is crucial to recognize that the coefficients link the environmental variables with the inefficiency $u_{i t}$. A positive coefficient therefore means that the respective variable affects efficiency negatively.

\section{Data}

To test our hypothesis with the aid of stochastic frontier analysis, we examined the expenditures for road construction and maintenance in Swiss cantons between 2000 and 2016. This analysis particularly benefits from the latitude cantons have in defining their expenditures (inputs) and the extent of public service provision (outputs) in both road infrastructure on the one side and the different contexts (environmental variables) within which the cantons function on the other side.

In terms of output, the construction and maintenance of roads is usually approximated by the road length (da Cruz and Marques 2014; Narbón-Perpiñá and De Witte 2017; Widmer and Zweifel 2012). To account for attrition, the number of cars reflects the frequency and intensity of use of these roads (Widmer and Zweifel 2012). As a qualitative measure of roads, the number of accidents due to bad road quality serves as a proxy (Kalb 2009). ${ }^{6}$ In line with the literature, the input side is quantified through expenditures instead of individual inputs and their prices (Balaguer-Coll, Prior, and TortosaAusina 2007; Seifert and Nieswand 2014; Widmer and Zweifel 2012), with total expenditures split into outlays for goods and services, personnel, and financial and capital purposes. Calculating deflated values guarantees comparability between the years. Together with an assumption of constant input prices among all observations, the results show the effect on technical instead of cost inefficiency (Seifert and Nieswand 2014; Kumbhakar, Wang, and Horncastle 2015). 
The main concerns with respect to environmental variables being the earmarked revenues requires some knowledge of how the respective accounting mechanism operates. It is designed to ensure earmarks are used only for a specific predefined purpose. ${ }^{7}$ For each specifically financed task - in our case for road provision - an individual account called an "earmarked fund" or "special financing" records both the earmarked revenue and the corresponding expenditure. The claimed exclusive use can thus be disclosed in full transparency. Simultaneously, earmarked revenues enter the general financial statement, subsumed under total revenues. Likewise, the corresponding expenditures form part of the total expenditures presented in the annual financial statement. However, in the year-end reporting, the earmarked revenues and their corresponding expenditures are given as net figures independent of all other transactions. If their balance is positive (i.e. if earmarked revenues are larger than corresponding expenditure), then a credit note increases the respective account in the balance sheet (i.e. the earmarked fund). In case of a negative balance, the account decreases by the amount of the deficit (see Figure 4 in the appendix for an illustration). Putting these two cases together implies not only that the earmarked revenue must be exclusively used for its specified purpose, but also that no other funding source is made available for that purpose. In other words, a crowding out of financial resources from the general budget through insufficient earmarked revenue is not possible in the Swiss cantonal system.

Unfortunately, there are no unified statistics about the use of the special financings, which is why we directly gathered our data from the only data source available, the annual cantonal financial statements. We use the expenditures funded by the stock of the earmarked fund (i.e. expenditures through earmarked funds) in per capita terms as a variable which approximates the phenomenon of earmarking. Figure 1 shows the importance of earmarking in the 26 Swiss cantons from 2000 to 2016 (abbreviations refer to specific cantons). Expenditures through earmarked funds remained roughly stable between 2000 and 2007. They began increasing after the fiscal equalization system was modified in 2008, leading to greater variation between the cantons. On average by 2015 and 2016, earmarked expenditures accounted for about 30 percent of total expenditures for road construction and maintenance.

Alongside the debate prevention theory, a fiscal illusion created by other revenue characteristics may affect the efficiency of public service provision (Oates 1985). For instance, Wyckoff (1990) argues that the bureaucrat might successfully pocket rents from intergovernmental transfers. 
Figure 1 - Relevance of earmarked funds

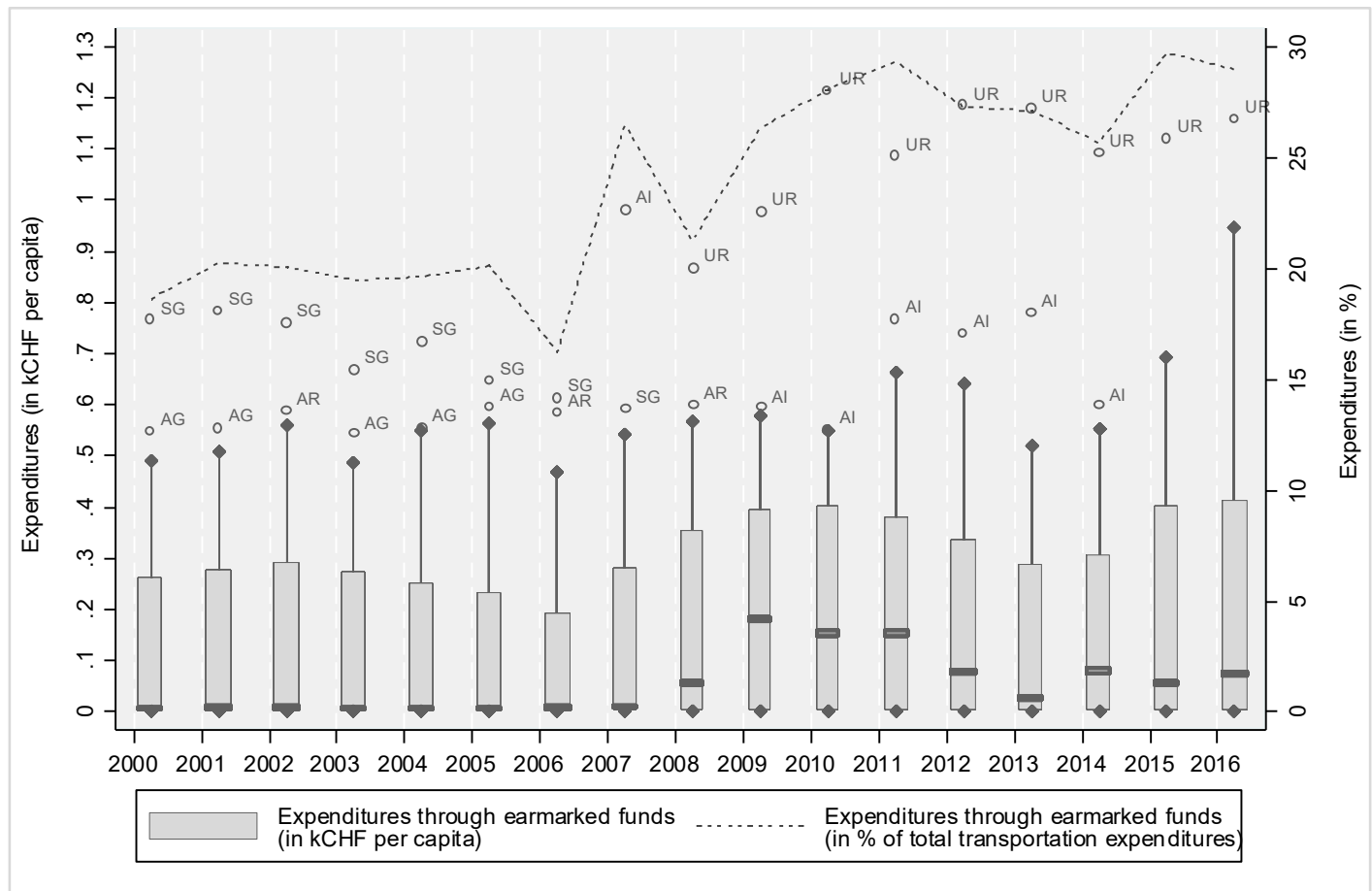

Grants from other state entities would then be a source of voter misperception of the government budget, which the bureaucrat could in turn exploit for his or her own use. These rents drive a wedge between the inputs (i.e. taxes) and the outputs (i.e. the public service provision), resulting in a lowered efficiency. A slack-maximizing bureaucrat is therefore a possible explanation for why grants are not transferred to the voter via reduced taxes while nevertheless leading to higher expenditures. The notion that money sticks where it hits came to be known as the flypaper effect (Courant, Gramlich, and Rubinfeld 1979). We capture this by introducing transfer receipts in our regression.

Certainly, grants are not the only source of possible misperceptions of the government budget, and Wyckoff's (1990) chain of reasoning also works with other sources of fiscal illusion. First, tax composition entails tax complexity. A highly complex tax structure makes it difficult for voters to maintain an overview of the total amount paid to the government. Thus, a higher revenue complexity purportedly reduces efficiency (Dollery and Worthington 1996). To measure tax complexity we follow Carroll (2009) in using the relative importance of each source $s_{i}$ to calculate a normalized HerfindahlHirschmann index $\mathrm{nHHi}^{8}$ Second, the income elasticity of the revenue system refers to the progressivity of the tax system. 
According to this theory, people are more aware of the tax rate than of their actual tax bill. If their income grows and they pay more due to tax progression, voters perceive the tax bill to be lower than when the tax rate increases (Oates 1975). As long as public expenditures can be funded without raising the tax rate, people will not oppose them (Dollery and Worthington 1996). The presumption is that a strongly progressive tax will have a more negative effect on efficiency than a flat tax. Tax progressivity is measured as a logarithmic parameter; the stronger the progressivity, the higher the values. ${ }^{9}$ Third, voters may experience debt illusions if the price they pay today does not fully reflect the true cost of the public service.

We also control for other confounding factors. If the obstacles to participating in the democratic process are low, the incentives for citizens to exercise their control function are higher (Widmer and Zweifel 2012; Geys, Heinemann, and Kalb 2010). This is operationalized using an index for financial referenda (Frey and Stutzer 2000). While the possibility of a referendum provides incentives to contribute to the political process, the participation rate in elections can also be measured directly. The expected effect on efficiency is also positive. Based on assumptions rather than deep theory, several studies have assessed the effect of party affiliation on efficiency, with the evidence generally showing that left-wing parties have a negative effect on efficiency (Kalb 2010; Borge, Falch, and Tovmo 2008). We control for political parties at both executive and legislative levels. Without a definite prediction of its effect, we follow similar studies controlling for the proportion of foreigners (Bönisch et al. 2011). Finally, we include the length of municipal and national roads as control variables, given that, within a canton, a long federal road system - funded by the central government rather than the subnational jurisdictions - will absorb more traffic and thus make cantonal expenditures per kilometer of road shrink. This variable also controls for potential scale effects, as we measure it as kilometers of road per square kilometer of the canton. ${ }^{10}$ Table 2 in the appendix provides the descriptive statistics. Indeed, some cantons operate in a more challenging context than others; road construction may be more costly, for example, due to the hilliness of certain cantonal terrains. However, these factors are not included among the environmental variables, because they are time-invariant and hence absorbed by the individual fixed-effect of the applied models.

\section{Results}

Table 1 (see appendix) shows the coefficient estimates, starting with the TFE model with TL specification (see Equation (2)) as the baseline regression (Model I). ${ }^{11}$ 
The top row of coefficients lists the inputs (I) and outputs (O) with the respective elasticities as well as the intercept. Note that all inputs and outputs are logarithmic and normalized by their mean value such that they can be interpreted as an average elasticity for all cantons and years. The second group represents the environmental variables that influence the inefficiency variance (the $\boldsymbol{\delta}$ of Equation (2)), where the bold variables are those capturing the revenue characteristics discussed in the theory section 2 and the data section 4 . The third group provides information about the stochastic noise (i.e. $\left.\hat{\sigma}_{v}\right)$, the inefficiency variance $\left(\hat{\sigma}_{u}\right)$ and the signal-to-noise ratio $(\hat{\lambda})$. A higher ratio is desirable as the inefficiency variance is necessary to identify the effects of the environmental variables (Badunenko, Henderson, and Kumbhakar 2012). In this respect, the TRE Model (II) is the best as its ratio exceeds 1 . The last group provides further standard information.

Focusing first on the inputs and outputs, only a few of the coefficients are statistically significant. That could help reduce complexity and be used to estimate a Cobb-Douglas model. However, a ttest, which sets all additional coefficients of a translog specification equal to zero, rejects the null hypothesis. The likelihood ratio test finds a significant difference between the two models, which speaks in favor of the more flexible translog model. Among the environmental variables of interest, all five revenue characteristics are significant. While the expenditures through earmarked funds, transfers, and debt yield the expected positive sign (i.e. they affect efficiency negatively), tax progressivity and complexity are associated with less inefficiency. Since only marginal effects can be interpreted, Figure 2 illustrates the respective values. They indicate by what percentage the input requirement changes due to an increase of the respective environmental variable by one unit. ${ }^{12}$ In line with Kumbhakar and Sun (2013), we also find that their marginal effects fall short of the ones proposed by Wang (2002) in absolute terms; for the sake of being cautious, we discuss the more conservative values of Kumbhakar and Sun.

As for the expenditures through earmarked funds, increasing them by 1,000 Swiss francs per capita demands on average 5.4 percent more inputs. This effect accelerates as the earmarked fund expenditures rise, though it stabilizes at around 14 percent when the initial level of expenditures through earmarked funds amounts to 800 Swiss francs per capita.

The estimated effects of tax progressivity and complexity runs counter to our expectations. Increasing progressivity, from an index value of 3.4 to 9.4 , by one, reduces inefficiency by 4.8 
percent, on average. Likewise, increasing the complexity of the tax system by one standard deviation (+7.60) cuts inefficiency, on average, by 5.1 percent.

Figure 2 - Marginal effects of the revenue characteristics of full model (I)



Tax complexity



Transfers as share of total revenue
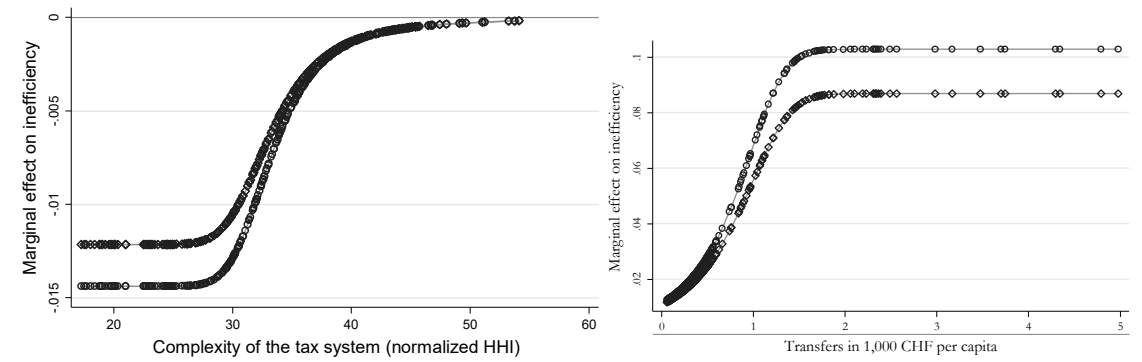

Debt per capita



$\diamond \quad$ Marginal effect on $\mathrm{E}[\mathrm{u} \mid \mathrm{e}]$ (Kumbhakar \& Sun)

- Marginal effect on $\mathrm{E}[\mathrm{u} \mid \mathrm{u}>0]$ (Wang)

In support of the flypaper effect hypothesis, additional transfers of 1,000 Swiss francs per capita enhance inefficiency by 3.1 percent, on average. Debt illusion also seems to play a role, since 6,207 (one standard deviation) Swiss francs of additional debt translate on average into 2.8 percent more inefficiency.

We contrast these results with those of various robustness checks (see Figure 3 in the appendix). Overall, and most importantly, all robustness checks support our initial findings. Model (II) reestimates Model (I) using the TRE estimator (Greene 2005). The mean marginal effect of the expenditures through earmarked funds drops to 1.5 percent. 
Yet, the two methods for calculating marginal effects produce more divergent results than the baseline model. Using the Cobb-Douglas specification (Model III), the average marginal effect amounts to 1.9 percent. Next, we account for the possibility that some of our controls might actually be outcomes themselves, and we drop them in Model (IV). The marginal effect of the expenditures through earmarked funds averages 3.6 percent. Model (V) re-estimates the baseline model including year fixed effects among the regressors of the frontier. The mean marginal effect of expenditures through earmarked funds jumps to 7.7 percent. We replace the variable of main interest by one that captures withdrawals from and deposits into earmarked funds. Since these transactions are more related to earmarked revenues than expenditures, and hence to external factors, we expect no effect on inefficiency. Indeed, the coefficient is not significant and economically negligible: increasing the deposits (reducing the withdrawals) by 1,000 Swiss francs per capita enhances inefficiency by 0.6 percent.

In two final tests, we twice employ algorithm \#2 of the two-step approach, as proposed by Simar and Wilson (2007). ${ }^{13}$ The first stage estimates the bias-corrected efficiency scores based on data envelopment analysis $(D E A)^{14}$ and the second stage runs a truncated regression of the environmental variables on the efficiency scores with bootstrapped standard errors. The nonparametric DEA differs fundamentally from stochastic frontier analysis, as it imposes no functional form a priori on the frontier while attributing the entire deviation from the frontier to inefficiency but not to stochastic noise (Cooper, Seiford, and Tone 2007). Instead of assuming a specific functional form of the frontier, DEA actually makes it possible to test the returns to scale (Simar and Wilson 2002). According to the test result, the more flexible but slower converging variable returns to scale specification is necessary..$^{15}$

While Model (VII) uses the full set of inputs and outputs for the first step, Model (VIII) follows Wilson (2018) and reduces the dimensionality to two for the sake of estimation efficiency. Usually, the two-step approach uses efficiency as dependent variable, which is why the coefficient has an inverse sign compared to the models above. A positive coefficient stands for a positive effect on efficiency and vice-versa. While this characteristic is valid for Model (VII), it does not hold true for Model (VIII). The latter regresses the environmental variables on the inverse efficiency, i.e. the Shephard distance measure, in the second step due to convergence issues. The sign of the coefficient therefore corresponds to those in the SFA models; however, the coefficient's value can 
hardly be intuitively interpreted. In line with our hypothesis, the estimated coefficient in Model (VII) is negative and statistically significant. ${ }^{16}$ As the model is linear, the coefficient can be interpreted directly. As expenditures rise using earmarked funds of 1,000 Swiss francs per capita, it leads to a 17.4 percent fall in efficiency. In other words, after expenditures rise, the canton should reduce its inputs by 17.4 percent while leaving output production at the same level in order to be fully efficient. Model (VIII) supports the robustness of this result with its significant and positive coefficient related to expenditures by earmarked funds. Overall, the positive effect on inefficiency found previously is supported by the two-step approach.

\section{Conclusion}

Given that the literature lacks consensus over whether earmarked revenues should be considered beneficial or detrimental to efficiency, this paper introduces a new point of view centered around debate prevention. According to this view, earmarking negatively affects efficiency in that it reduces supervision among and between ministers on the governing council. Without the incentive to control their colleagues' work, the spending ministers can segregate a part of the government budget, and this leads to an inefficient provision of services.

Debate prevention theory adds to the fiscal illusion literature that considers revenue characteristics to explain efficiency in providing public services in general, and transport infrastructure in particular. It thus offers a compeling rationale to the expectations and to the empirical evidence that, alongside traditional factors like debt, transfer funding, tax complexity or progressivity, earmarking negatively affects efficiency.

We use the stochastic frontier analysis to combine several inputs and outputs into an inefficiency measure, one that can also be explained by certain environmental variables. We checked the robustness of our finding with a non-parametric two-step approach based on data envelopment analysis. Swiss cantonal data of road infrastructure provided the data, which covers twenty-one of the twenty-six cantons from 2000 to 2016.

The results show the expected negative effect of earmarking on efficiency of the road construction and maintenance. The estimates support the debate prevention theory. They also put into perspective previous findings arguing that earmarking had no effect on the expenditures (Nesbit and Kreft 2009; Dye and McGuire 1992). On average, additional expenditures through earmarked funds of 1,000 Swiss 
francs lead to an increase of input requirements by 5.4 percent. Previous studies mentioned a crowding out effect to explain the absence of a significant coefficient. However, this explanation is not valid in the Swiss case due to the specific definition of special financing (see Section 4) (Nesbit and Kreft 2009). As a matter of fact, the data used here provide an interesting opportunity to disentangle crowding out effects from the actual effects earmarking has on efficiency.

Regarding other revenue characteristics, the coefficients are relatively stable and robust, and usually significant. The effect of transfers and debt are in line with the expectations. On the contrary, tax progressivity and complexity are positively associated with efficiency meaning that they do not create fiscal illusion in the investigated area.

Our study is limited by its relatively narrow focus on the assessment of technical efficiency, even though earmarking also affects budget allocations. Accordingly, these results do not comment on any possible contingent increase or loss in social welfare due to earmarked funds. Moreover, the study proposes a possible mechanism through which earmarking might affect efficiency. At the same time, it cannot exclude other channels that could potentially lead to the same outcome.

Furthermore, the applied methodological approaches cannot exclude endogeneity between environmental variables and efficiency. ${ }^{17}$ One might argue that the parliament installs earmarked funds with the intention to control and discipline an existing inefficient behaviour of the executive. In this case, the causality would run in the opposite direction of that claimed in the debate prevention theory. Yet, two arguments work against reverse causality. First, the cantonal parliaments in Switzerland cannot influence the expenditure variations of earmarked funds but only their initial setup or cancellation. Hence, if the parliament were reacting on an inefficient behaviour of the executive, we would observe frequent setups and cancellations of earmarked funds which is not the case. Second, data about earmarked funds shows that the correlation coefficient of the expenditures by earmarked funds and the earmarked funds count is rather low. This means that expenditure variation comes from external (and exogenous) sources such as a higher fuel demand which mainly contributes to the earmarked fund to construct roads.

We see two prominent paths toward deepening knowledge in the field of earmarked funding and efficiency. First, as the stochastic frontier analysis is highly data-driven, the number of observations should be dramatically increased in order to enhance the power of the estimations. Second, the effect found could be domain-specific, since the ministries of transport engage in some of the largest special 
financing of all policy areas in the Swiss cantons. Other domains might then be different with respect to the transparency of the services provided and therefore show deviant effects. In consequence, expanding our empirical tests to other domains seems rather promising. 


\section{Appendix}

\section{Tables}

Table 1 - Estimation results

\begin{tabular}{|c|c|c|c|c|c|c|c|c|}
\hline & $\begin{array}{r}\text { True fixed effects } \\
\text { model }(I)\end{array}$ & $\begin{array}{l}\text { True random } \\
\text { effects model (II) }\end{array}$ & Cobb -Douglas (III) & $\begin{array}{r}\text { No control variables } \\
\text { (IV) }\end{array}$ & Time dummies (V) & $\begin{array}{r}\text { Deposits and } \\
\text { withdrawals (VI) }\end{array}$ & $\begin{array}{r}\text { Data envelopment } \\
\text { Analysis (VII) }\end{array}$ & $\begin{array}{r}\text { Data envelopment } \\
\text { Analysis reduced } \\
\text { Inputs/Outputs } \\
\text { (VIII) }\end{array}$ \\
\hline 11: operational expenditure & $-0.152^{* * *}(0.043)$ & $-0.175 * * *(0.027)$ & $-0.131 * * *(0.047)$ & $-0.148^{* * *}(0.045)$ & $-0.150 * * *(0.024)$ & $-0.139 * * *(-0.139)$ & & \\
\hline 12: capital expenditure & $0.015(0.023)$ & $0.013(0.025)$ & $-0.012(0.037)$ & $0.000(0.030)$ & $-0.035(0.034)$ & $0.009(0.009)$ & & \\
\hline $12^{2}$ & $0.169 * * *(0.063)$ & $0.162 * * *(0.044)$ & & $0.145^{* *}(0.070)$ & $0.156^{* * *}(0.041)$ & $0.178^{* *}(0.178)$ & & \\
\hline $13^{2}$ & $0.032(0.051)$ & $0.046(0.036)$ & & $0.029(0.050)$ & $-0.004(0.047)$ & $0.039(0.039)$ & & \\
\hline $12 \times 13$ & $-0.070(0.062)$ & $-0.106 * *(0.053)$ & & $-0.048(0.072)$ & $-0.057(0.066)$ & $-0.113(-0.113)$ & & \\
\hline O1: road length (in km) & $-0.507 *(0.277)$ & $0.116^{* * *}(0.039)$ & $-0.182(0.452)$ & $-0.504 *(0.272)$ & $-0.393(0.296)$ & $-0.640 * *(-0.640)$ & & \\
\hline O2: number of vehicles & $-0.030(0.029)$ & $-0.016(0.023)$ & $-0.056^{* *}(0.022)$ & $0.002(0.034)$ & $-0.041(0.034)$ & $0.003(0.003)$ & & \\
\hline $\begin{array}{l}\text { O3: accidents due to low road quality } \\
\text { (index: few [0] to many [100]) }\end{array}$ & $0.535(0.332)$ & $0.824 *(0.439)$ & $0.322 * *(0.130)$ & $1.194 *(0.624)$ & $0.777 *(0.454)$ & $0.792 * *(0.792)$ & & \\
\hline $\mathrm{O} 1^{2}$ & $-0.338(0.220)$ & $-0.265 * * *(0.028)$ & & $0.246(0.270)$ & $-0.063(0.240)$ & $-0.225(-0.225)$ & & \\
\hline $\mathrm{O} 2^{2}$ & $-0.029(0.040)$ & $-0.014(0.032)$ & & $-0.096 * *(0.047)$ & $-0.011(0.026)$ & $-0.040(-0.040)$ & & \\
\hline $\mathrm{O}^{2}$ & $0.529(1.320)$ & $-0.453(1.402)$ & & $2.096(1.686)$ & $2.792 *(1.438)$ & $-0.644(-0.644)$ & & \\
\hline $01 \times 02$ & $0.017(0.067)$ & $0.000(0.056)$ & & $0.004(0.080)$ & $-0.068(0.075)$ & $-0.039(-0.039)$ & & \\
\hline $01 \times 03$ & $-0.144(0.399)$ & $-0.544(0.667)$ & & $-0.313(0.755)$ & $-0.413(0.470)$ & $-0.797 *(-0.797)$ & & \\
\hline $02 \times 03$ & $-0.272(0.394)$ & $-0.439(0.469)$ & & $-0.521(0.497)$ & $0.315(0.331)$ & $-0.190(-0.190)$ & & \\
\hline $12 \times 01$ & $0.007(0.060)$ & $-0.005(0.048)$ & & $0.034(0.063)$ & $0.031(0.054)$ & $0.035(0.035)$ & & \\
\hline $12 \times 02$ & $-0.016(0.046)$ & $-0.001(0.040)$ & & $-0.046(0.057)$ & $-0.030(0.037)$ & $-0.031(-0.031)$ & & \\
\hline $12 \times 03$ & $0.065(0.249)$ & $0.089(0.319)$ & & $0.377(0.283)$ & $0.147(0.186)$ & $-0.109(-0.109)$ & & \\
\hline $13 \times 01$ & $-0.059(0.047)$ & $-0.035(0.048)$ & & $-0.073(0.066)$ & $-0.077(0.048)$ & $-0.066(-0.066)$ & & \\
\hline $13 \times 02$ & $0.062^{* *}(0.030)$ & $0.063 *(0.037)$ & & $0.081 *(0.042)$ & $0.072^{* * *}(0.027)$ & $0.082 * *(0.082)$ & & \\
\hline $13 \times 03$ & $-0.021(0.176)$ & $0.101(0.209)$ & & $-0.177(0.217)$ & $-0.208(0.176)$ & $0.069(0.069)$ & & \\
\hline intercept $\left(\alpha_{0}\right)$ & & $-0.389 * * *(0.030)$ & & & & & & \\
\hline
\end{tabular}


Table 1 - Estimation results (continued)

\begin{tabular}{|c|c|c|c|c|c|c|c|c|}
\hline & $\begin{array}{r}\text { True fixed effects } \\
\text { model(I) }\end{array}$ & $\begin{array}{r}\text { True random effects } \\
\text { model (II) }\end{array}$ & Cobb -Douglas (III) & $\begin{array}{r}\text { No control variables } \\
\text { (IV) }\end{array}$ & Time dummies (V) & $\begin{array}{r}\text { Deposits and } \\
\text { withdrawals (VI) }\end{array}$ & $\begin{array}{r}\text { Data envelopment } \\
\text { Analysis (VII) }\end{array}$ & $\begin{array}{r}\text { Data envelopment } \\
\text { Analysis reduced } \\
\text { Inputs/Outputs (VIII) }\end{array}$ \\
\hline Expenditures by earmarked funds (in & $0.163^{* *}(0.074)$ & $0.184 * * *(0.057)$ & $0.213 *(0.120)$ & $0.221^{* * *}(0.078)$ & $0.239 * * *(0.089)$ & & $-0.174^{* * *}(0.032)$ & $11.951^{* * *}(3.060)$ \\
\hline kCHF per capita) & & & & & & & & \\
\hline $\begin{array}{l}\text { Lagged expenditures through earmarked } \\
\text { fund }\end{array}$ & & & & & & & & \\
\hline $\begin{array}{l}\text { deposits to and withdrawals from } \\
\text { earmarked fund (in kCHF per capita) }\end{array}$ & & & & & & $0.155(0.155)$ & & \\
\hline Tax progressivity (curvature parameter) & $-0.115^{* * *}(0.032)$ & $-0.139 * * *(0.040)$ & $-0.090 *(0.050)$ & $-0.057 *(0.029)$ & $-0.064(0.044)$ & $-0.171(-0.171)$ & $0.018 *(0.011)$ & $-2.097 *(0.885)$ \\
\hline Tax complexity (normalized HHI) & $-0.014^{* * *}(0.002)$ & $-0.017 * * *(0.004)$ & $-0.012^{* * *}(0.004)$ & $-0.002(0.006)$ & $-0.010 * *(0.004)$ & $-0.013 * * *(-0.013)$ & $0.004^{* * *}(0.001)$ & $0.006(0.116)$ \\
\hline Transfers (in kCHF per capita) & $0.103^{* * *}(0.024)$ & $0.078^{*}(0.042)$ & $0.125(0.112)$ & $0.189 * *(0.087)$ & $0.159 *(0.085)$ & $0.066 * *(0.066)$ & $-0.055^{* * *}(0.016)$ & $-0.828(1.305)$ \\
\hline Gross debt (in KCHF per capita) & $0.016^{* *}(0.007)$ & $0.045^{* * *}(0.013)$ & $0.038^{* * *}(0.014)$ & $0.034 * * *(0.009)$ & $0.010(0.012)$ & $0.035 *(0.035)$ & $-0.017^{* * *}(0.003)$ & $-0.014(0.283)$ \\
\hline GDP (in kCHF per capita) & $0.005(0.004)$ & $-0.006 * *(0.003)$ & $-0.002(0.004)$ & & $0.001(0.003)$ & $-0.009 *(-0.009)$ & $-0.003 *(0.002)$ & $0.208(0.155)$ \\
\hline Referendum (1 [hard] to 6 [easy]) & $0.049(0.033)$ & $0.109 * * *(0.031)$ & $0.028(0.048)$ & & $0.011(0.024)$ & $0.031(0.031)$ & $-0.007(0.015)$ & $0.721(1.298)$ \\
\hline Participation rate in polls (in percent) & $0.000(0.000)$ & $-0.004 *(0.003)$ & $0.000 *(0.000)$ & & $0.000(0.002)$ & $0.000(0.000)$ & $0.000(0.000)$ & $0.021(0.082)$ \\
\hline Foreigners (in \% of total inhabitants) & $-0.033 *(0.017)$ & $-0.062 * *(0.025)$ & $-0.047 * *(0.020)$ & & $0.010(0.008)$ & $-0.056(-0.056)$ & $0.022 * * *(0.005)$ & $-0.353(0.362)$ \\
\hline Non-cantonal streets (in m per km²) & $0.333^{* * *}(0.088)$ & $0.297^{* * *}(0.063)$ & $0.193^{* * *}(0.060)$ & & $0.022(0.038)$ & $0.437 * *(0.437)$ & $-0.546(0.474)$ & $-78.349(70.004)$ \\
\hline $\begin{array}{l}\text { Executive party orientation (left [1] to } \\
\text { right [10]) }\end{array}$ & $0.006(0.040)$ & $0.004(0.087)$ & $-0.060(0.110)$ & & $0.009(0.038)$ & $0.050(0.050)$ & $-0.013(0.016)$ & $-3.604 * * *(1.333)$ \\
\hline Right parties in legislative (in \%) & $0.056(0.159)$ & $0.003(0.002)$ & $0.283(0.288)$ & & $0.000(0.001)$ & $0.053(0.053)$ & $-0.114(0.080)$ & $0.090(0.071)$ \\
\hline Debt brake (weak [0] to restrictive [3]) & $-0.059 * *(0.023)$ & $-0.014(0.023)$ & $-0.004(0.026)$ & & $-0.040^{* * *}(0.015)$ & $-0.053(-0.053)$ & $0.024 * * *(0.008)$ & $-1.131(0.762)$ \\
\hline Intercept $\left(\delta_{0}\right)$ & $0.529(0.358)$ & $1.432 *(0.759)$ & $1.446(0.900)$ & $0.062(0.227)$ & $0.295(0.277)$ & $1.435(1.435)$ & & \\
\hline $\mathbb{E}\left[\hat{\sigma}_{u}\right]$ & $0.033(0.030)$ & $0.074 * *(0.033)$ & $0.068(0.051)$ & $0.048(0.044)$ & $0.050(0.048)$ & $0.061(0.071)$ & & \\
\hline $\mathbb{E}\left[\hat{\sigma}_{v}\right]$ & $0.076^{* * *}(0.009)$ & $0.072 * * *(0.009)$ & $0.077^{* * *}(0.017)$ & $0.080^{* * *}(0.013)$ & $0.057 * *(0.026)$ & $0.069 * * *(0.020)$ & & \\
\hline $\mathbb{E}[\hat{\lambda}]\left(=\mathbb{E}\left[\hat{\sigma}_{u}\right] / \mathbb{E}\left[\hat{\sigma}_{v}\right]\right)$ & $0.429 * * *(0.036)$ & $1.028 * * *(0.040)$ & $0.874 * * *(0.066)$ & $0.598^{* * *}(0.055)$ & $0.885^{* * *}(0.073)$ & $0.878^{* * *}(0.090)$ & & \\
\hline Log-likelihood & 376.808 & 280.543 & 343.395 & 347.509 & 416.706 & 385.060 & & \\
\hline Model & TFE & TRE & TFE & TFE & TFE & TFE & $\begin{array}{l}\text { DEA (Farrell), Simar- } \\
\text { Wilson algorithm \#2 }\end{array}$ & $\begin{array}{r}\text { DEA (Shephard), } \\
\text { Simar-Wilson } \\
\text { algorithm \#2 }\end{array}$ \\
\hline Time dummies & no & no & no & no & yes & no & no & no \\
\hline $\mathrm{N}$ & 337 & 337 & 337 & 337 & 337 & 337 & 337 & 337 \\
\hline
\end{tabular}

Notes: I = inputs; O = outputs; TFE = true fixed effects; TRE = true random effects, coefficients with robust standard errors clustered at cantonal level; the dependent variable is the logged personnel expenditures; all variables of the frontier are in logarithms and normalized by their mean value; ${ }^{*} \mathrm{p}=90 \%, * * \mathrm{p}=95 \%, * * * \mathrm{p}=99 \%$; the first group indicates the $\beta$ (inputs; I) and $\alpha$ (output; 0 ) coefficients; the second group shows the delta coefficients $\left(\mu_{u, i t}=\boldsymbol{\delta}^{\prime} z_{i t}\right)$; the third group lists the signal-to-noise ratio $\lambda$ and its ingredients. 
Table 2 - Descriptive statistics

\begin{tabular}{|c|c|c|c|c|c|}
\hline Variable group & Variable & Mean & $\begin{array}{l}\text { Standard } \\
\text { deviation }\end{array}$ & Minimum & Maximum Data Source ${ }^{b}$ \\
\hline \multirow[t]{3}{*}{ Inputs } & Personnel expenditure (in kCHF) & $13,332.457$ & $10,955.151$ & 570.413 & $45,838.516$ federal finance administration \\
\hline & Operational expenditure (in $\mathrm{kCHF}$ ) & $17,980.644$ & $21,901.746$ & 472.451 & $122,332.886$ federal finance administration \\
\hline & Capital expenditure (in kCHF) & $67,952.606$ & $74,283.693$ & $1,314.098$ & $436,857.017$ federal finance administration \\
\hline \multirow[t]{3}{*}{ Outputs } & road length (in km) & 624.819 & 614.354 & 48 & 2111 federal statistical office \\
\hline & vehicles (no.) & 203,017 & $218,187.614$ & 9,520 & 938,520 federal statistical office \\
\hline & $\begin{array}{l}\text { accidents due to low road quality } \\
\left(\text { index }^{\text {a }} \text { ) }\right.\end{array}$ & 96.683 & 7.326 & 53.317 & 100 federal roads office \\
\hline \multirow[t]{5}{*}{$\begin{array}{l}\text { Revenue } \\
\text { characteristics }\end{array}$} & $\begin{array}{l}\text { Expenditures through special } \\
\text { financing (in kCHF per capita) }\end{array}$ & 0.187 & 0.266 & 0 & $\begin{array}{l}1.215 \text { cantonal annual financial } \\
\text { statements }\end{array}$ \\
\hline & $\begin{array}{l}\text { Tax progressivity (curvature } \\
\text { parameter) }\end{array}$ & 6.197 & 1.699 & 3.270 & 9.399 federal tax administration \\
\hline & Tax complexity (normalized HHI) & 34.664 & 7.599 & 17.237 & 54.118 federal finance administration \\
\hline & Transfers (in kCHF per capita) & 0.643 & 0.768 & 0.058 & 4.975 federal finance administration \\
\hline & $\begin{array}{l}\text { Gross debt per capita (in kCHF per } \\
\text { capita) }\end{array}$ & 6.412 & 6.207 & 1.048 & 36.283 federal finance administration \\
\hline \multirow{8}{*}{$\begin{array}{l}\text { Further } \\
\text { environmental } \\
\text { variables }\end{array}$} & GDP (in kCHF per capita) & 57.892 & 19.389 & 39.003 & 176.513 BAK Basel Economics AG \\
\hline & $\begin{array}{l}\text { Referendum (from } 1 \text { [hard] to } 6 \\
\text { [easy]) }\end{array}$ & 5.013 & 1.268 & 2.25 & 6 mainly federal statistical office \\
\hline & $\begin{array}{l}\text { Participation rate in polls (in } \\
\text { percent) }\end{array}$ & 46.305 & 7.031 & 27.431 & 69.262 federal statistical office \\
\hline & $\begin{array}{l}\text { Foreigners (in percent of total } \\
\text { inhabitants) }\end{array}$ & 18.916 & 6.897 & 7.819 & 40.984 federal statistical office \\
\hline & $\begin{array}{l}\text { Non-cantonal streets (in meters } \\
\text { per } \mathrm{km}^{2} \text { ) }\end{array}$ & 1.736 & 1.218 & 0.175 & 4.661 federal statistical office \\
\hline & $\begin{array}{l}\text { Executive party orientation (left [1] } \\
\text { to right [10]) }\end{array}$ & 5.548 & 0.617 & 4.22 & 7.057 federal statistical office \\
\hline & $\begin{array}{l}\text { Right-wing parties in legislative (in } \\
\%)\end{array}$ & 0.43 & 0.144 & 0 & 0.646 federal statistical office \\
\hline & $\begin{array}{l}\text { Debt brake (weak [0] to restrictive } \\
\text { [3]) }\end{array}$ & 1.092 & 1.108 & 0 & $\begin{array}{l}3 \text { cantonal constitutions and laws } \\
\text { (Feld and Kirchgässner) }\end{array}$ \\
\hline
\end{tabular}

${ }^{\text {a } I n d e x ~ c a l c u l a t e d ~ a s ~} y^{i}=a-b * y^{b}$ with $a=100+\frac{99 * \arg \min \left(y^{b}\right)}{\arg \max \left(y^{b}\right)-\arg \min \left(y^{b}\right)}$ and $b=\frac{99}{\arg \max \left(y^{b}\right)-\arg \min \left(y^{b}\right)}$ and $y^{b}=$ bad output

${ }^{\mathrm{b}}$ All data are subject to own calculations based on the data source indicated in the last column

Notes: Without missing values there should be 442 observations ( 26 cantons and 17 years); the true $\mathrm{N}=337$; missing cantons (and years) are

BS (if year < 2013), VD (all years), TG (all years), TI (2015, 2016) LU (all years), GR (all years), GL (all years), GE (2014 to 2016), VS (2015, 2016) 
Figures

Figure 3-Marginal effects of the expenditures through special financings in different models
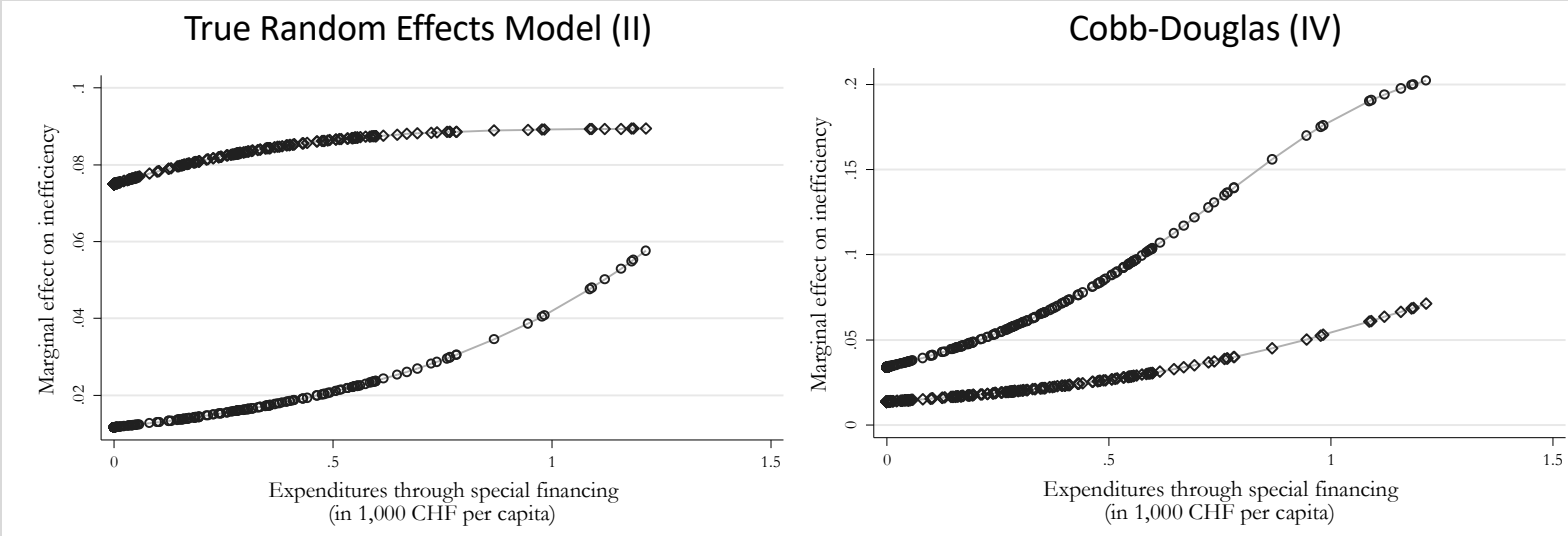

No control variables $(\mathrm{V})$

Time dummies (VI)
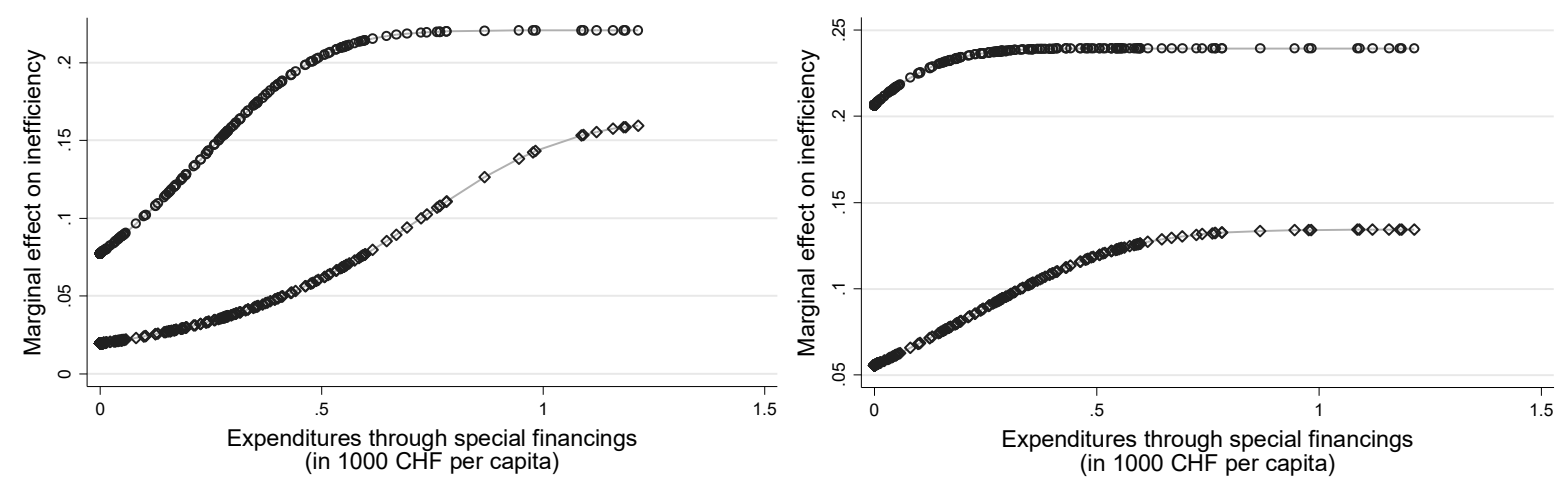

Deposits and withdrawals (VII)

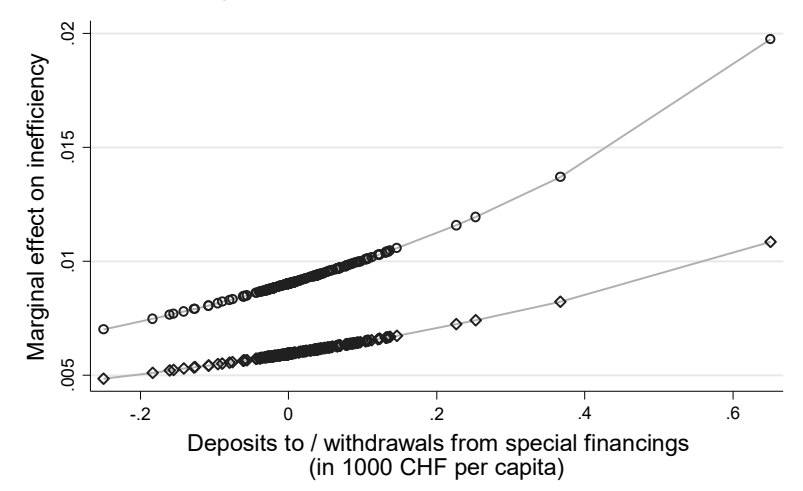

$\begin{array}{ll}\diamond & \text { Marginal effect on } E[\mathrm{u} \mid \mathrm{e}] \text { (Kumbhakar \& Sun) } \\ 0 & \text { Marginal effect on } \mathrm{E}[\mathrm{u} \mid \mathrm{u}>0] \text { (Wang) }\end{array}$

Source: Own illustration 
Figure 4-Accounting scheme of earmarked funds

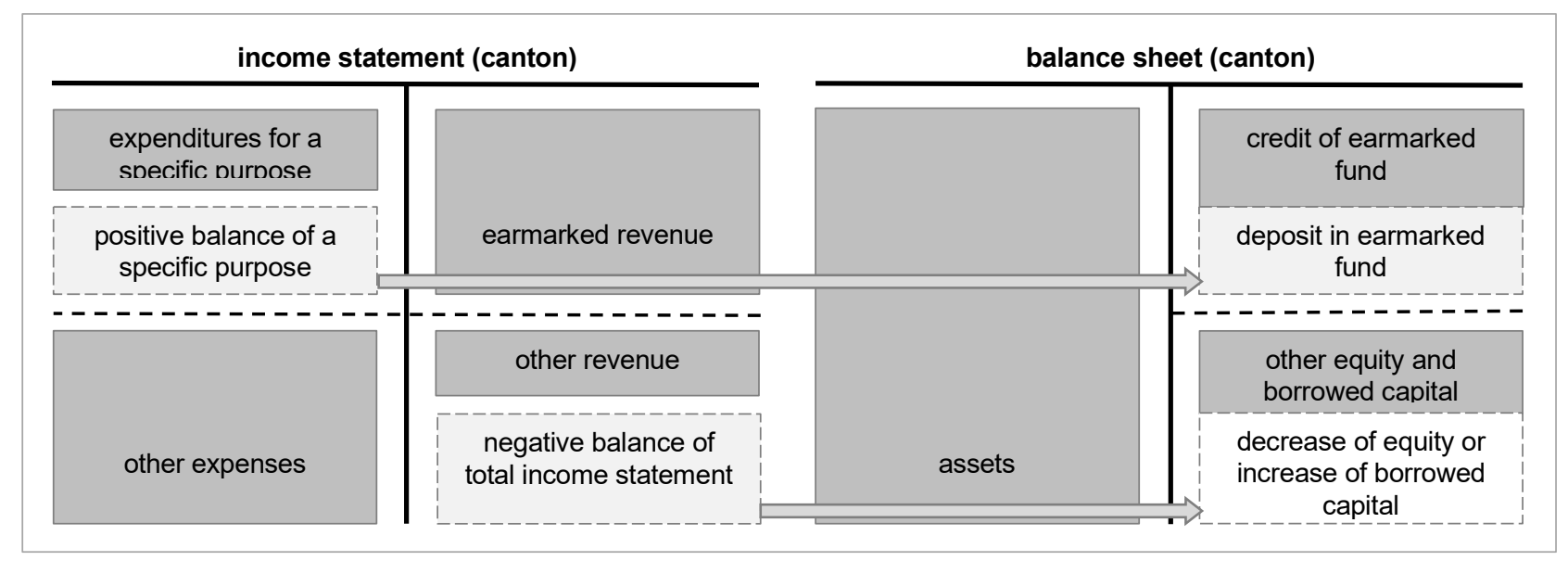

\section{Acknowledgements}

We thank Reiner Eichenberger (University of Fribourg, CH), Mehdi Farsi (University of Neuchâtel, $\mathrm{CH}$ ), Christian Thöni (University of Lausanne), the Editor-in-Chief, the Associate Editor and an anonymous reviewer for their critical contributions during the development of the paper. Furthermore, we are indebted to Michelle BailatJones and John Bendix for their editing assistance.

\section{Declaration of Conflicting Interests}

The authors declared no potential conflicts of interest with respect to the research, authorship, and/or publication of this article.

\section{Funding}

The funding came solely from the University of Lausanne.

\section{Endnotes}

1. For a discussion of how monitoring potentially disciplines the ministers see Nagin et al. (2002).

2. Formally, a production function that is homogenous of degree one in inputs satisfies the following condition:

$y * \lambda^{\gamma}=f\left(x_{1} \gamma, x_{2} \gamma, \ldots, x_{n} \gamma\right)$. If $\gamma=1$, which is not assumed here, the proportional increase in outputs is the same as the proportional increase in inputs and the production function has constant returns to scale.

3. Note that the required identification constraints to satisfy the homogeneity property are different for the Cobb-Douglas and the translog specification. Kumbhakar (2012) discusses them extensively.

4. Using an input rather than an output-oriented distance function is justified by the discretionary power of the administration. Production analyses in the public sector usually estimate input-oriented 
efficiencies, because the outputs are usually fixed by law, and the administration strongly influences the expenditures (Seifert and Nieswand 2014).

5. While Wang (2002) calculates marginal effects based on a post-truncation mean of inefficiency, i.e. $\frac{\partial E\left(u_{i t} \mid u_{i t}>0\right)}{\partial z_{i t}}$, Kumbhakar and Sun (2013) condition on the entire error term, i.e. $\frac{\partial E\left(u_{i t} \mid \epsilon_{i t}\right)}{\partial z_{i t}}$.

6. Since accidents are an undesirable variable, it enters here in the transformed form as index (see Table 2).

7. Of course, different understandings are possible. For a classification of different types of earmarked funds see Bird and Jun (2005). According to their typology, earmarked revenue as we present it would be categorized as substantive earmarking, where an increase in earmarked revenues has a direct effect on the special fund or the linked expenditures.

8. The $\mathrm{nHHI}$ is defined as $n H H I=\left(\left(\sum_{i=1}^{N} s_{i}^{2}\right)-1 / N\right) /(1-1 / N)$. See Pommerehne and Schneider (1978) who used Swiss data in a similar way in an early empirical paper on the subject.

9. The tax progressivity parameter $a$ results as an estimate when fitting a logarithmic function into a xy-plane that plots the tax rate $t$ against income $y_{i}$. The logarithmic function reads as $t\left(y_{i}\right)=a *$ $\ln \left(y_{i}\right)+b$.

10. Some studies (da Cruz and Marques 2014; Geys, Heinemann, and Kalb 2010) use population density to control for scale effects. However, this variable is strongly correlated (0.89) with the federal road variable. Accordingly, we included only the latter to avoid collinearity.

11. Estimates are based on Stata's sfpanel command (Belotti et al. 2015). Marginal effects are based on our own calculations.

12. Due to convergence problems in the bootstrap replications, we cannot report confidence intervals for the marginal effects as proposed by Kumbhakar and Sun (2013).

13. Applying the simarwilson command in Stata (Badunenko and Tauchmann 2019), we use the following specifications: Input oriented with variable returns to scale; 200 replications for the bias correction and 2000 replications for the bootstrap to estimate standard errors.

14. Spearman's rank correlation between the efficiency scores of the baseline model and the ones from DEA comes only to 0.2. But the test that the two efficiency estimates are independent is rejected at the $99 \%$ level.

15. The $\hat{S}_{2 n}^{c r s}$-statistic is estimated using the heterogenous bootstrap with 2000 replications. 
16. The same estimation with the constant returns to scale specification yields rather different coefficients with inversed signs for the variables of interest. Since this specification is wrong according to the $\hat{S}_{2 n}^{c r s}$-test (see Footnote 15$)$, we are not worried about this difference.

17. Recent developments in SFA allow implementing instrumental variables to overcome endogeneity issues. In particular, they drop the assumption of an uncorrelated inefficiency term with the stochastic noise. Increasing the model flexibility this way potentially alters the results dramatically (Kutlu, Tran, and Tsionas 2019).

\section{References}

Afonso, Whitney B. 2015. Leviathan or Flypaper: Examining the Fungibility of Earmarked Local Sales Taxes for Transportation. Public Budgeting \& Finance 35 (3): 1-23.

Badunenko, Oleg, Daniel J. Henderson, and Subal C. Kumbhakar. 2012. When, Where and How to Perform Efficiency Estimation. Journal of the Royal Statistical Society: Series A (Statistics in Society) 175 (4): 863-892.

Badunenko, Oleg, and Harald Tauchmann. 2019. Simar and Wilson two-stage efficiency analysis for Stata. The Stata Journal 19 (4): 950-988.

Balaguer-Coll, Maria Teresa, Diego Prior, and Emili Tortosa-Ausina. 2007. On the Determinants of Local Government Performance: A Two-Stage Nonparametric Approach. European Economic Review 51 (2): 425-451.

Battese, George E, and Tim J Coelli. 1988. Prediction of Firm-Level Technical Efficiencies with a Generalized Frontier Production Function and Panel Data. Journal of Econometrics 38 (3): 387-399.

Belotti, Federico, Silvio Daidone, Vincenzo Atella, and Giuseppe Ilardi. 2015. SFPANEL: Stata Module for Panel Data Stochastic Frontier Models Estimation. Stata command.

Bird, Richard M. 1982. Budgeting and Expenditure Control in Columbia. Public Budgeting \& Finance 2 (3): 87-99.

Bird, Richard M, and Joosung Jun. 2005. Earmarking in Theory and Korean Practice. International Tax Program Papers 513, Toronto, Ont.

Bönisch, Peter, Peter Haug, Annette Illy, Lukas Schreier. 2011. Municipality Size and Efficiency of Local Public Services: Does Size Matter? IWH Discussion Papers 18, Halle, ST 
Borge, Lars-Erik, Torberg Falch, and Per Tovmo. 2008. Public Sector Efficiency: The Roles of Political and Budgetary Institutions, Fiscal Capacity, and Democratic Participation. Public Choice 136 (3): $475-$ 495.

Buchanan, James M. 1963. The Economics of Earmarked Taxes. The Journal of Political Economy 71 (5): 457-469.

Carroll, Deborah A. 2009. Diversifying Municipal Government Revenue Structures: Fiscal Illusion or Instability? Public Budgeting \& Finance 29 (1): 27-48.

Cooper, William W., Lawrence M. Seiford, and Kaoru Tone. 2007. Data Envelopment Analysis: A Comprehensive Text with Models, Applications, References and DEA-Solver Software. Second Edition. New York: Springer US.

Courant, Paul N., Edward M. Gramlich, and Daniel L. Rubinfeld. 1979. The Stimulative Effects of Intergovernmental Grants: Or Why Money Sticks Where It Hits. In Fiscal Federalism and Grants-in-Aid. Peter Mieszkowski and William H. Oakland, ed., 127-143. Washington, D.C.: Urban Institute

Da Cruz, Nuno Ferreira, and Rui Cunha Marques. 2014. Revisiting the Determinants of Local Government Performance. Omega 44 (2): 91-103.

Deran, Elizabeth. 1965. Earmarking and Expenditures: A Survey and a New Test. National Tax Journal 18 (4): 354-361.

Dollery, Brian E., and Andrew C. Worthington. 1996. The Empirical Analysis of Fiscal Illusion. Journal of Economic Surveys 10 (3): 261-297.

Dye, Richard F., and Therese J. McGuire. 1992. The Effect of Earmarked Revenues on the Level and Composition of Expenditures. Public Finance Review 20 (4): 543-556.

Feld, Lars P, and Gebhard Kirchgässner. 2008. On the Effectiveness of Debt Brakes: The Swiss Experience. In Sustainability of Public Debt. Reinhard Neck and Jan-Egbert Sturm, ed., 223-255. Cambridge, MA: MIT Press

Frey, Bruno S, and Alois Stutzer. 2000. Happiness, Economy and Institutions. The Economic Journal 110 (466): 918-938.

Geys, Benny, Friedrich Heinemann, and Alexander Kalb. 2010. Voter Involvement, Fiscal Autonomy and Public Sector Efficiency: Evidence from German Municipalities. European Journal of Political Economy 26 (2): 265-278. 
Greene, Willam H. 2005. Fixed and Random Effects in Stochastic Frontier Models. Journal of Productivity Analysis 23 (1): 7-32.

Jackson, Jeremy. 2013. Tax Earmarking, Party Politics and Gubernatorial Veto: Theory and Evidence from US States. Public Choice 155 (1): 1-18.

Kalb, Alexander. 2009. What Determines Local Governments' Technical Efficiency? The Case of Road Maintenance. ZEW - Centre for European Economic Research Discussion Paper No. 09-047. Mannheim, BW

Kalb, Alexander. 2010. The Impact of Intergovernmental Grants on Cost Efficiency: Theory and Evidence from German Municipalities. Economic Analysis and Policy 40 (1): 23-48.

Kumbhakar, Subal C. 2012. Specification and Estimation of Primal Production Models. European Journal of Operational Research 217 (3): 509-518.

Kumbhakar, Subal C., and Kai Sun. 2013. Derivation of Marginal Effects of Determinants of Technical Inefficiency. Economics Letters 120 (2): 249-253.

Kumbhakar, Subal C., Hongren Wang, and Alan P. Horncastle. 2015. A Practitioner's Guide to Stochastic Frontier Analysis Using Stata. New York: Cambridge University Press.

Kutlu, Levent, Kien C. Tran, and Mike G. Tsionas. 2019. A Time-Varying True Individual Effects Model with Endogenous Regressors. Journal of Econometrics 211 (2): 539-559.

Lee, Dwight R., and Richard E. Wagner. 1991. The Political Economy of Tax Earmarking. In Charging for Government: User Charges and Earmarked Taxes in Principle and Practice, Richard E Wagner, ed., 110-124. New York: Routledge.

Martínez, Luis R. 2014. Sources of Revenue and Government Performance: Theory and Evidence from Colombia. Unpublished manuscript, Chicago, IL.

McCleary, William. 1991. The Earmarking of Government Revenue: A Review of Some World Bank Experience. The World Bank Research Observer 6 (1): 81-104.

Nagin, Daniel S., James B. Rebitzer, Seth Sanders, and Lowell J. Taylor. 2002. Monitoring, Motivation, and Management: The Determinants of Opportunistic Behavior in a Field Experiment. The American Economic Review 92 (4): 850-873.

Narbón-Perpiñá, Isabel, and Kristof De Witte. 2018. Local Governments' Efficiency: A Systematic Literature Review - part I. International Transactions in Operational Research 25 (2): 431-468. 
Nesbit, Todd M., and Steven F. Kreft. 2009. Federal Grants, Earmarked Revenues, and Budget Crowd-out: State Highway Funding. Public Budgeting \& Finance 29 (2): 94-110.

Niskanen, William A. 1975. Bureaucrats and Politicians. The Journal of Law \& Economics 18 (3): 617643.

Oates, Wallace E. 1975. Automatic Increases in Tax Revenues: The Effect on the Size of the Public Budget. In Financing the New Federation. Revenue Sharing, Conditional Grants and Taxation. Wallace E Oates, ed., 139-160. Baltimore, MD: Johns Hopkins University Press.

Oates, Wallace E. 1985. On the Nature and Measurement of Fiscal Illusion: A Survey. In Taxation and Fiscal Federalism: Essays in Honour of Russell Mathews. Geoffrey Brennan, Bhajan Singh Grewal, and Peter D. Groenewegen, ed., 65-82. Sydney, CU: Australian National University Press.

Persson, Torsten, and Guido E. Tabellini. 2002. Political Economics: Explaining Economic Policy. Cambridge, MA: MIT press.

Polo, Michele. 1998. Electoral Competition and Political Rents. IGIER Working Paper 144, Milan, LOM.

Pommerehne, Werner W., and Friedrich Schneider. 1978. Fiscal Ollusion, Political Institutions, and Local Public Spending. Kyklos 31 (3): 381-408.

Roberts, Alasdair. 2002. Lockbox Government: Segregated Funding Strategies and the Decline of Governmental Flexibility. Governance 15 (2): 241-270.

Schönenberger, Alain. 2013. Öffentliche Finanzen der Schweiz. In Handbuch der öffentlichen Verwaltung in der Schweiz, Andreas Ladner, Jeann-Loup Chappelet, Yves Emery, Peter Knoepfel, Luzius Mader, Nils Soguel, Frédéric Varone, ed., 565-585. Zurich, ZH: Verlag Neue Zürcher Zeitung.

Seifert, Stefan, and Maria Nieswand. 2014. What Drives Intermediate Local Governments' Spending Efficiency: The Case of French Départements. Local Government Studies 40 (5): 766-790.

Shephard, Ronald W. 1953. Cost and Production Functions. Princeton, NJ: Princeton University Press.

Simar, Léopold, and Paul W. Wilson. 2007. Estimation and Inference in Two-Stage, Semi-Parametric Models of Production Processes. Journal of Econometrics 136 (1): 31-64.

Simar, Léopold, and Paul W. Wilson. 2002. Non-Parametric Tests of Returns to Scale. European Journal of Operational Research 139 (1): 115-132. 
Wang, Hung-Jen. 2002. Heteroscedasticity and Non-Monotonic Efficiency Effects of a Stochastic Frontier Model. Journal of Productivity Analysis 18 (3): 241-253.

Widmer, Philippe, and Peter Zweifel. 2012. Fiscal Equalization, Tiebout Competition, and Incentives for Efficiency in a Federalist Country. Public Finance Review 40 (1): 3-29.

Wilson, Paul W. 2018. Dimension Reduction in Nonparametric Models of Production. European Journal of Operational Research 267 (1): 349-367.

Wyckoff, Paul Gary. 1990. The Simple Analytics of Slack-Maximizing Bureaucracy. Public Choice 67 (1): 35-47.

\section{Author Biographies}

Ramon Christen works at PwC Switzerland with a focus on public sector advisory. Before he obtained his PhD in Public Administration from the University of Lausanne, he was visiting scholar at the State University New York at Binghamton. He gained practical experience in the field of public finance from engagements in different positions and different state layers in Swiss public administrations.

Nils C. Soguel is a professor of Public Finance at the Swiss Graduate School of Public AdministrationIDHEAP (University of Lausanne). He is chair of the Swiss Public Sector Financial Reporting Advisory Committee. He holds a Ph.D. in economics. His research interests include public sector financial management, fiscal policy, fiscal federalism and the valuation of non-market good. 